The Milesians: Thales 


\section{Traditio Praesocratica}

Zeugnisse frühgriechischer Philosophie und ihres Fortlebens

Textual evidence on early Greek philosophy and its continuation

Volume 1 


\section{The Milesians: Thales}

Edited by

Georg Wöhrle

Translation and additional material by

Richard McKirahan

With collaboration of

Ahmed Alwishah

With an introduction by

Georg Wöhrle and Gotthard Strohmaier 
ISBN 978-3-11-031510-3

e-ISBN (PDF) 978-3-11-031525-7

e-ISBN (EPUB) 978-3-11-038199-3

Library of Congress Cataloging-in-Publication Data

A CIP catalog record for this book has been applied for at the Library of Congress.

Bibliografische Information der Deutschen Nationalbibliothek

The Deutsche Nationalbibliothek lists this publication in the Deutsche Nationalbibliografie; detailed bibliographic data are available on the Internet at http://dnb.dnb.de.

(C) 2014 Walter de Gruyter GmbH, Berlin/Boson

Typesetting: Dörlemann-Satz GmbH \& Co. KG, Lemförde

Printing and binding: Hubert \& Co. GmbH \& Co. KG, Göttingen

( ) Printed on acid-free paper.

Printed in Germany.

www.degruyter.com 